\title{
Correction to: Cherry-picking the Wrong Patients?
}

\author{
Jens Fiehler ${ }^{1}$ Götz Thomalla • Martin Bendszus ${ }^{3}$
}

Published online: 21 June 2021

(c) The Author(s) 2021

\section{Correction to:}

\section{Clin Neuroradiol 2020}

https://doi.org/10.1007/s00062-020-00878-2

The article "Cherry-picking the Wrong Patients?" by Jens Fiehler, Götz Thomalla, and Martin Bendszus, was originally published electronically on the publisher's internet portal on 6 February 2020 without open access. With the author(s)' decision to opt for open choice the copyright of the article changed on 21 April 2021 to "ㅇ The author(s) 2020" and the article is forthwith distributed under a Creative Commons Attribution 4.0 International License, which permits use, sharing, adaptation, distribution and reproduction in any medium or format, as long as appropriate credit is given to the original author(s) and the source, provide a link to the Creative Commons licence, and indicate if changes were made.
Funding. Open access funding enabled and organized by Projekt DEAL.

Open Access This article is licensed under a Creative Commons Attribution 4.0 International License, which permits use, sharing, adaptation, distribution and reproduction in any medium or format, as long as you give appropriate credit to the original author(s) and the source, provide a link to the Creative Commons licence, and indicate if changes were made. The images or other third party material in this article are included in the article's Creative Commons licence, unless indicated otherwise in a credit line to the material. If material is not included in the article's Creative Commons licence and your intended use is not permitted by statutory regulation or exceeds the permitted use, you will need to obtain permission directly from the copyright holder. To view a copy of this licence, visit http://creativecommons.org/licenses/by/4. $0 /$.

The online version of the original article can be found under https://doi.org/10.1007/s00062-020-00878-2.

Jens Fiehler

fiehler@uke.de

1 Department of Neuroradiology, University Medical Center, Hamburg-Eppendorf, Hamburg, Germany

2 Department of Neurology, University Medical Center, Hamburg-Eppendorf, Hamburg, Germany

3 Department of Neuroradiology, Heidelberg University Hospital, Heidelberg, Germany 